Original Research

\title{
Continuous and controllable electro-fabrication of antimicrobial copper-alginate dressing for infected wounds treatment
}

\author{
Shijia Wang ${ }^{1} \cdot$ Xiaoli Liu ${ }^{1} \cdot$ Miao Lei ${ }^{1} \cdot$ Junjie Sun ${ }^{1} \cdot$ Xue Qu ${ }^{1}{ }^{1} \cdot$ Changsheng Liu $^{1}$
}

Received: 22 September 2020 / Accepted: 26 October 2021 / Published online: 24 November 2021

(c) The Author(s) 2021

\begin{abstract}
The contamination of chronic wound with bacteria especially methicillin-resistant Staphylococcus aureus (MRSA) is considered as the major factor interferencing normal wound healing. There still remain great challenges in developing safe and effective wound dressings with wide-spectrum antibacterial functions. Alginate hydrogel is a common dressing for wound treatment. Copper is one of the trace elements in human body with inherent antibacterial activity. Traditional methods for preparing a structure-controlled copper-alginate antibacterial matrix are difficult however, due to the fast and uncontrolled gelation between alginate and metal ions. In this work, we report an electrodeposition method for rapid fabrication of copper cross-linked alginate antibacterial films $\left(\mathrm{Cu}^{2+}-\mathrm{Alg}\right)$ with controlled structure and copper content, which is relied on an electrical signal controlled release of copper ions from the reaction of insoluble salt $\mathrm{Cu}_{2}(\mathrm{OH})_{2} \mathrm{CO}_{3}$ and the generated protons via water electrolysis on anode. The results prove that the physical structure and chemical composition of the electrodeposited $\mathrm{Cu}^{2+}$-Alg films can be continuously modulated by the imposed charges during electrodeposition. In vitro tests demonstrate the film has $\mathrm{Cu}^{2+}$ content-dependent bactericidal activities. Film's cytocompatibility is well controlled by the imposed charges for $\mathrm{Cu}^{2+}$-Alg fabrication. The MRSA infected wound model in vivo also indicates that $\mathrm{Cu}^{2+}$-Alg film can effectively eliminate bacterial infection and suppress host inflammatory responses. We believe this study demonstrates a convenient and controllable strategy to fabricate alginate antibacterial dressings with potential applications for infected wound treatment. More broadly, our work reveals electrodeposition is a general and simple platform to design alginate films with versatile functions.
\end{abstract}

These authors contributed equally: Shijia Wang, Xiaoli Liu

Supplementary information The online version contains supplementary material available at https://doi.org/10.1007/s10856021-06619-2.

Xue Qu

quxue@ecust.edu.cn

$\triangle$ Changsheng Liu liucs@ecust.edu.cn
1 Key Laboratory for Ultrafine Materials of Ministry of Education, Frontiers Science Center for Materiobiology and Dynamic Chemistry, School of material science and engineering, East China University of Science and Technology, Shanghai 200237, China 


\section{Graphical Abstract}

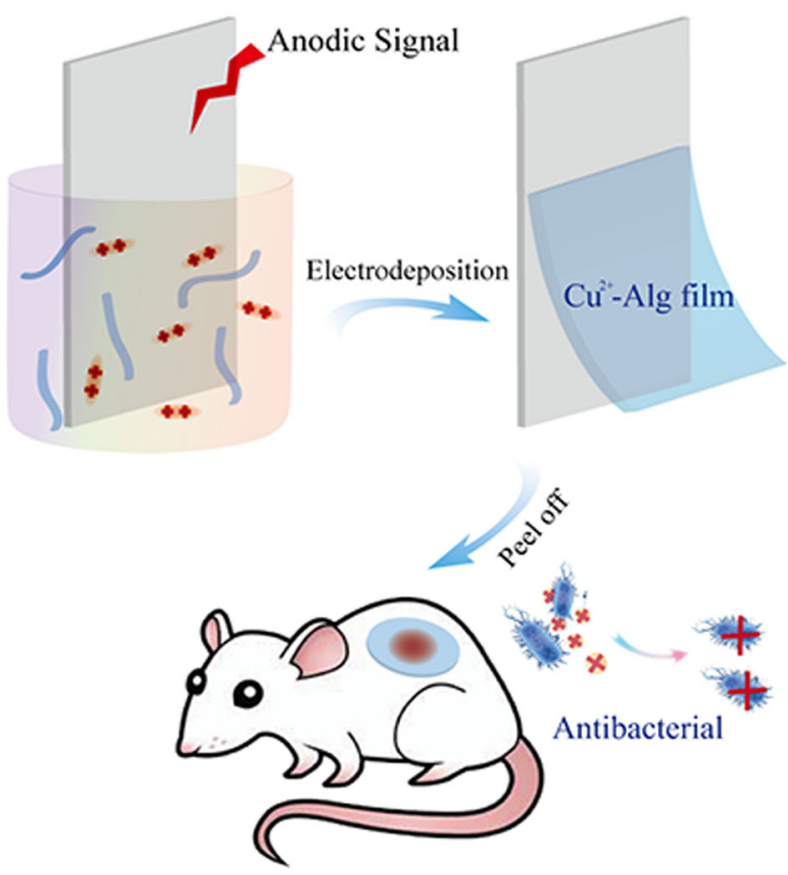

\section{Introduction}

As the aging population and diseases such as diabetes, obesity, and heart disease are proven to be associaDted with wound healing, the risk of tractable wounds being transferred to chronic wounds increases dramatically [1,2]. Normally, the natural process of wound healing involves four classic stages: hemostasis, inflammation, proliferation, and remodeling [3, 4]. Chronic wounds are characterized by prolonged inflammation and delayed healing, which are associated with diminished neovascularization and re-epithelization [5]. Bacterial infections are considered to be a major local factor to the detriment of wound healing, which lead to a prolonged excessive inflammatory response and delay in collagen synthesis and epithelialization [6, 7]. In particular, microbiological studies have confirmed that chronic wound infection with methicillinresistant Staphylococcus aureus (MRSA) is a growing worldwide problem [8-10]. Hence, superior wound treatment using dressings with wide-spectrum antimicrobial bioactivities is highly recommended $[11,12]$.

Alginate (Alg) is a commonly used dressing material due to its advantages such as readily available, biocompatible and non-toxic [13-16]. Its organic part is composed of $\mathrm{M}$ units ( $\beta$-D-mannuronate) and $\mathrm{G}$ units ( $\alpha$-L-guluronate) and these two units are linked by 1,4 glycoside bonds in different ratios [17]. Most polyvalent metal ions (such as $\mathrm{Cu}^{2+}, \mathrm{Ca}^{2+}, \mathrm{Zn}^{2+}, \mathrm{Co}^{2+}$, $\mathrm{Ba}^{2+}$ ) can undergo an ion exchange reaction with an aqueous sodium alginate solution to form another insoluble alginate
$[18,19]$. And this process can cause a so-called "egg-box" structure with a planar two-dimensional manner, which further leads to the formation of ionic cross-linked hydrogels [20]. Copper is one of the 26 essential nutrients in human, participating in the metabolic activities [21]. Additionally, copper has been widely reported for its broad antibacterial properties [2225]. In 2008, copper was the first metal to receive EPA certification [26]. The report pointed out that elemental copper, copper oxide, copper ions $\left(\mathrm{Cu}^{2+}\right)$, etc., all have excellent antibacterial properties against different strains [27]. However, $\mathrm{Cu}$ has potential hazards in excess of cellular needs, so the delivery of $\mathrm{Cu}$ has to be strictly controlled in a narrow therapeutic window and precisely regulated for potential biomedical applications [28-30].

So far, $\mathrm{Cu}^{2+}$-Alg matrix was mainly investigated with respect to its antimicrobial activity [31], while few reports regarded it as a potential candidate for wound dressings. This is mainly because that the conventional methods for preparing $\mathrm{Cu}^{2+}$-Alg based materials, like impregnation and electrostatic extrusion, are time-consuming and laborintensive $[32,33]$. Methods like impregnation also have difficulties in obtaining homogeneous films with accurate control of $\mathrm{Cu}^{2+}$ contents due to the strong affinity between $\mathrm{Cu}^{2+}$ and $\mathrm{Alg}[34,35]$. Therefore, exploring a simple, mild and reproducible method for preparing highly uniform $\mathrm{Cu}^{2+}$-Alg dressings and accurately controlling the copper content is highly required for developing advanced antibacterial dressings. 


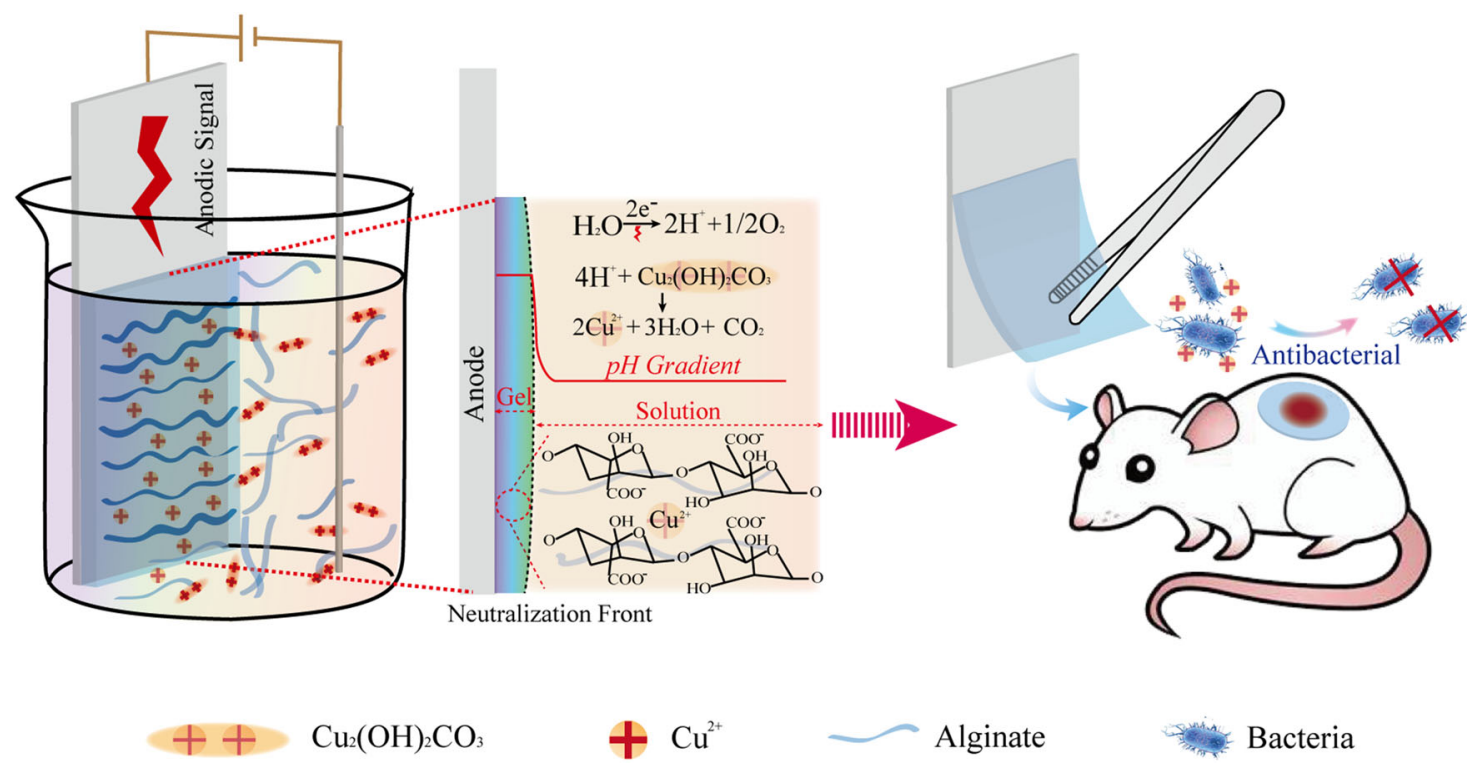

Scheme 1 Mechanism of copper alginate $\left(\mathrm{Cu}^{2+}-\mathrm{Alg}\right)$ film prepared by electrodeposition: electrochemically generated protons from the anode surface trigger the release of $\mathrm{Cu}^{2+}$ ions from insoluble $\mathrm{Cu}_{2}(\mathrm{OH})_{2} \mathrm{CO}_{3}$ particles. The free $\mathrm{Cu}^{2+}$ ions interact with the alginate and cross-link

Electrodeposition technology has attracted a lot of attention in material fabrication field in recent years [36-38]. Mechanically, programmable electric signals with exquisite spatiotemporal and quantitative control are imposed to initiate varying electrolytic reactions, which can induce material formation and further modification in-situ [39-42]. Its main advantages are including (1) simple, mild and rapid material molding [16, 43]; (2) continuous and controllable modulation of material's inner structures and chemical characteristics [39, 44]; (3) creation of complex 3D structures by changing the shape of electrodes [45-47].

Here, we propose a novel electro-fabrication methodology to controllably prepare $\mathrm{Cu}^{2+}-\mathrm{Alg}$ dressings. Scheme 1 summarizes the mechanism for $\mathrm{Cu}^{2+}$-Alg fabrication and its potential application as antibacterial dressing. $\mathrm{Cu}_{2}(\mathrm{OH})$ ${ }_{2} \mathrm{CO}_{3}$ serves as the resource of copper ions. After suspending $\mathrm{Cu}_{2}(\mathrm{OH})_{2} \mathrm{CO}_{3}$ into the $\mathrm{Alg}$ solution, a threeelectrode system is placed into it and an instantaneous current is applied to trigger the electrolysis of water. Protons are thus continually generated to form a $\mathrm{pH}$ gradient at the anode surface, by which the suspended $\mathrm{Cu}_{2}(\mathrm{OH})_{2} \mathrm{CO}_{3}$ particles near the anode area are gradually dissolved to release $\mathrm{Cu}^{2+}$ to crosslink alginate. During this process, a uniform $\mathrm{Cu}^{2+}$-Alg hydrogel is formed on the anodic surface, which can be peeled off completely and serve as a free-standing film. This electro-fabrication method offers several unique advantages over other conventional methods: (1) films can be prepared in a quite short time (within a few minutes); (2) $\mathrm{Cu}^{2+}$ distribution is more uniform due to a controlled ion releasing mechanism; (3) the physical structure (i.e. the polymer chains to form a hydrogel film on the electrode surface rapidly. The peeled $\mathrm{Cu}^{2+}$-Alg dressing releases dose-controlled $\mathrm{Cu}^{2+}$ to fight bacteria and improve infected wound healing

thickness) and chemical composition (i.e. $\mathrm{Cu}$ content) of the films can be precisely modulated via charge transfer (Q); (4) porous structure is created by the simultaneously generated $\mathrm{O}_{2}$ and $\mathrm{CO}_{2}$ on anode. We demonstrate the $\mathrm{Cu}^{2+}$-Alg film confers copper ion content-dependent antimicrobial activity in vitro. Its onset time is shorter than commercial silver dressings, while has comparable or better cytocompatibility decided by the $\mathrm{Cu}^{2+}$ amount. A rat subcutaneous antimicrobial model demonstrates that the electro-fabricated $\mathrm{Cu}^{2+}$-Alg film has strong antibacterial ability towards MRSA in vivo. We believe our work provides a simple and controllable novel method for fabricating $\mathrm{Cu}^{2+}$-Alg based antibacterial hydrogel dressing for chronic wound management. More broadly, this study demonstrates the electrodeposition method is promising to construct new structure and confer functions for achieving high performance materials.

\section{Materials and methods}

\subsection{Materials}

Sodium alginate and cupric subcarbonate were purchased from Sigma-Aldrich. Live/dead BacLight Bacterial Viability Kit was purchased from Invitrogen. The commercial dressing Biatain ${ }^{\circ}$ Alginate $\mathrm{Ag}$ was purchased from Advanced Medical Solutions Ltd. Other reagents were purchased form Aladdin chemistry unless otherwise specified. The chemicals were used without further purification. 


\subsection{Electro-fabrication of $\mathrm{Cu}^{2+} / \mathrm{Ca}^{2+}$-Alg films}

The three-electrode system (CHI660E, Chenhua Shanghai) was used for electrodeposition, employing platinum plate $\left(1.5 \times 1.5 \mathrm{~cm}^{2}\right)$ as the working electrode (anode), Pt wire as the counter electrode (cathode) and $\mathrm{Ag} / \mathrm{AgCl}$ as the reference electrode.

For $\mathrm{Cu}^{2+}$-Alg films, the electrolyte was prepared by dissolving sodium alginate $(0.8 \mathrm{wt} \%)$ and $\mathrm{Cu}_{2}(\mathrm{OH})_{2} \mathrm{CO}_{3}$ $(0.5 \mathrm{wt} \%)$ in ultrapure water with constant stirring for $5 \mathrm{~h}$. The electrodeposition process was performed by immersing the electrodes into electrolyte and then applying a constant current density $\left(1.78-4.44 \mathrm{~mA} / \mathrm{cm}^{2}\right.$ on demand) for predetermined time $(90 \mathrm{~s})$. The resultant copper alginate-coated electrode was rinsed extensively with ultrapure water. After then, a free-standing $\mathrm{Cu}^{2+}$-Alg film was peeled off from the anode.

The consumed anodic charges were calculated according to the Eq. (1):

Anodic charge $(\mathrm{Q})=\int i d t ; \mathrm{C}$

where $i$ is the instant anodic current density $\left(\mathrm{A} / \mathrm{cm}^{2}\right), t$ is the anodic oxidation time $(\mathrm{sec})$.

$\mathrm{Cu}^{2+}$-Alg films prepared by varying charges are denoted as $\left(\mathrm{Cu}^{2+}-\mathrm{Alg}\right)_{\mathrm{q}}$, where $\mathrm{q}$ indicates the consumed charge amount.

According to our previously reported method [16], the $\mathrm{Ca}^{2+}$-Alg film was prepared by dissolving sodium alginate $(1 \mathrm{wt} \%)$ and $\mathrm{CaCO}_{3}(0.5 \mathrm{wt} \%)$ in ultrapure water and employing electrodeposition method as same as mentioned above.

\subsection{Characterizations of $\mathrm{Cu}^{2+}-$ Alg films}

The hydrogel films' thickness was tested by an electronic spiral micrometer.

The hydrogel films were first frozen at $-18{ }^{\circ} \mathrm{C}$ for $12 \mathrm{~h}$ in the freezer (KK20V40TI, Siemens, Germany) and then freeze-dried at a temperature under $30^{\circ} \mathrm{C}$ and a pressure of $18 \mathrm{~Pa}$ for $24 \mathrm{~h}$ in a freeze-dryer (SCIENTZ-10N, Ningbo Scientz Biotechnology Co, Ltd., China).

The freeze-dried films were carefully handled and cut to extract the fraction of interest. SEM morphological analysis was performed on the scanning electron microscope (S-4800, Hitachi) at an accelerating voltage of $15 \mathrm{kV}$. The obtained SEM surface images were analyzed by Image $\mathrm{J}$ to get the pore size. Meanwhile, the fracture surface of $\mathrm{Cu}^{2+}$-Alg films was also be observed by SEM and the obtained images were employed to measure the thickness of freeze-dried films. The elemental analysis and compositional distribution of $\mathrm{Cu}^{2+}-\mathrm{Alg}$ films were measured using energy dispersive spectroscopy (QUANTAX 400-30, BRUKER AXS).
The interconnected porosity was calculated as the interconnected void volume over the total volume. Experimentally, to determine the total volume, films were soaked in ethanol for $1 \mathrm{~h}$ and weighted. A Kimwipe was then used to wick away ethanol within interconnected pores, and the films were weighted once again. The interconnected void volume was calculated as the volume of ethanol wicked from the films $[39,48]$.

To evaluate the films' mechanical properties, a tensile test was carried out by an ElectroForce ${ }^{\oplus}$ test instrument (Load Frame 3230 System, BOSE, USA) at stretch velocity of $0.01 \mathrm{~mm} / \mathrm{s}$. The dry films were cut into strips $(5 \mathrm{~mm}$ in width with an initial length of $10 \mathrm{~mm}$ ). The stress and strain at failure of different films were obtained from the stress strain curve. $(n=3)$.

\subsection{Quantitative analysis of $\mathrm{Cu}^{2+}$ content}

Electrodeposited $\mathrm{Cu}^{2+}$-Alg films with a series of charge amount were dissolved in an ion chelator, sodium citrate solution $(2 \mathrm{mg} / \mathrm{mL})$, respectively. Then it was placed in a $37{ }^{\circ} \mathrm{C}$ constant temperature oscillation box to fully dissolve films and free the $\mathrm{Cu}^{2+}$ cross-linked within the alginate films. Followed by centrifuging $(8000 \mathrm{r} / \mathrm{min}$, $10 \mathrm{~min}$ ), the supernatant was analyzed by an inductively coupled plasma atomic emission spectrometer (ICP-AES, Perkin-Elmer Optima). All tests were performed in triplicate.

\subsection{Decomposing of $\mathrm{Cu}^{2+}$-Alg film}

A $\left(\mathrm{Cu}^{2+}-\mathrm{Alg}\right)_{0.54 \mathrm{C}}$ film with the size of $1.5 \times 1.5 \mathrm{~cm}^{2}$ was put into $1 \mathrm{~mL}$ phosphate buffer saline (PBS) media and then placed in the $37^{\circ} \mathrm{C}$ shaker. The decomposing time of $\left(\mathrm{Cu}^{2+}-\mathrm{Alg}\right)_{0.54 \mathrm{C}}$ film was recorded.

\subsection{In vitro antimicrobial experiments}

\subsubsection{Bacterial culture and preparation}

Gram-negative bacteria Escherichia coli (ATCC 25922), gram-positive bacteria S. aureus (ATCC 25923) and MRSA acquired from hospital (Second Affiliated Hospital of Zhejiang University) were used in this study. Both gramnegative and gram-positive bacteria were firstly grown in the corresponding media, Luria-Bertani and Tryptic Soy Broth, respectively, for $24 \mathrm{~h}$ in a $37^{\circ} \mathrm{C}$ oscillation box. After quantified by diluted plate assay, the bacterial suspensions were washed completely to remove the bacterial culture media and re-suspended by $0.9 \%$ physiological saline to a certain concentration, following stored in $4{ }^{\circ} \mathrm{C}$ for further use. 


\subsubsection{Antibacterial test}

$S$. aureus and E. coli were chosen in this study. Electrodeposited copper alginate film $\left(\mathrm{Cu}^{2+}-\mathrm{Alg}\right)_{0.54 \mathrm{C}}(1.5 \times$ $1.5 \mathrm{~cm}^{2}$ ) was put into the 24 well plate for test. The bacterial culture plate was set as the negative control sample and the commercial dressing Biatain Alginate $\mathrm{Ag}\left(1.5 \times 1.5 \mathrm{~cm}^{2}\right)$ was set as positive control sample. For each group, $1 \mathrm{~mL}$ of bacteria solution $\left(10^{7} \mathrm{CFU} / \mathrm{mL}\right)$ was added into the sample well, and incubated at $37^{\circ} \mathrm{C}$. Each group had three replicate samples.

After incubation for 0.5 and $10 \mathrm{~h}$, the number of bacteria was obtained by using dilution plate counting. The antibacterial efficiency was calculated by the following formula:

$$
\text { Antibacterial efficiency }(\%)=[(\mathrm{A}-\mathrm{B}) / \mathrm{A}] \times 100 \%
$$

where $\mathrm{A}$ is the number of bacterial colonies on blank control, B is the number of bacterial colonies on films.

\subsubsection{Comparison of antibacterial properties within different films}

In order to evaluate and compare the antibacterial effect of electrodeposition $\mathrm{Cu}^{2+}$-Alg films prepared under different conditions, three groups $\left(\mathrm{Cu}^{2+}-\mathrm{Alg}\right)_{0.36 \mathrm{C}},\left(\mathrm{Cu}^{2+}-\mathrm{Alg}\right)_{0.54 \mathrm{C}}$, $\left(\mathrm{Cu}^{2+}-\mathrm{Alg}\right)_{0.72 \mathrm{C}}$ were used in this experiment. All the groups were placed into the 24 well plate for test with the same size of $1.5 \times 1.5 \mathrm{~cm}^{2}$. The bacterial culture plate was set as the negative control sample. Each group has three replicate samples. Then, $1 \mathrm{~mL}$ of $E$. coli suspensions $\left(10^{7}\right.$ $\mathrm{CFU} / \mathrm{mL}$ ) was added into each sample well, and incubated at $37^{\circ} \mathrm{C}$ for $10 \mathrm{~h}$. After that, the killing efficiency of $E$. coli was calculated by determined dilution for plate counting as mentioned before.

\subsubsection{The inhibition zone assay}

$\left(\mathrm{Cu}^{2+}-\mathrm{Alg}\right)_{0.54 \mathrm{C}}$ film was cut into $8 \mathrm{~mm}$ diameter discs for test. Electrodeposited calcium alginate film $\left(\mathrm{Ca}^{2+}-\mathrm{Alg}\right)_{0.54 \mathrm{C}}$ was used as the negative control sample with the same size. $200 \mu \mathrm{L}$ of $S$. aureus and E. coli suspensions $\left(10^{7} \mathrm{CFU} / \mathrm{mL}\right)$ were firstly introduced onto the agar plates, and then the films were placed onto the plates and incubated for $12 \mathrm{~h}$ at $37^{\circ} \mathrm{C}$.

\subsubsection{The protein leakage assay}

$\left(\mathrm{Cu}^{2+}-\mathrm{Alg}\right)_{0.54 \mathrm{C}}$ films were co-incubated with $S$. aureus and E. coli suspensions in the 24 well plate and the blank plate was set as the negative control sample. The volume and concentration of bacteria suspensions for each well was
$1 \mathrm{~mL}$ and $1 \times 10^{7} \mathrm{CFU} / \mathrm{mL}$, respectively. After $10 \mathrm{~h}$ incubation, the bacteria suspensions were collected through centrifuging with $8000 \mathrm{rpm}$ for $5 \mathrm{~min}$. Finally, the protein concentration in the supernatant was determined by a BCA protein kit (BCA assay, beyuntime).

\subsubsection{SEM observation of bacterial morphology}

The bacteria before and after $\left(\mathrm{Cu}^{2+}-\mathrm{Alg}\right)_{0.54 \mathrm{C}}$ film treatment for $10 \mathrm{~h}$ were fixed in $2 \%$ glutaraldehyde (GA) for $2 \mathrm{~h}$. Then the immobilized bacteria were collected by centrifugation at $8000 \mathrm{rpm}$ for $10 \mathrm{~min}$, and then experienced gradient dehydration. Afterwards, the bacteria solution was dropped onto silicon wafer, followed by freeze-drying and SEM imaging.

\subsubsection{Live/dead bacterial assay}

Live/dead bacterial assay was performed to examine the viability of bacteria before and after $\left(\mathrm{Cu}^{2+}-\mathrm{Alg}\right)_{0.54 \mathrm{C}}$ films treatment. For each group, $1 \mathrm{~mL}$ of bacteria solution $\left(10^{7}\right.$ $\mathrm{CFU} / \mathrm{mL}$ ) was added onto the plate with film, and then incubated for $10 \mathrm{~h}$. The bacteria solution was mixed with $100 \mu \mathrm{L}$ of dye solution containing $1.67 \mathrm{mM}$ of SYTO 9 dye and $20 \mathrm{mM}$ of propidium iodide for $20 \mathrm{~min}$ at room temperature. Then the bacteria were imaged using a confocal laser scanning microscopy.

\subsection{Biocompatibility evaluation}

\subsubsection{Cell culture and preparation}

Human umbilical vein endothelial cells (HUVECs) were chosen to estimate the biocompatibility of $\mathrm{Cu}^{2+}$-Alg films and Ag dressing, firstly grown in Dulbecco's modified Eagle's medium and then cultured in tissue culture flasks in a humidified $5 \% \mathrm{CO}_{2}$ environmental incubator at $37{ }^{\circ} \mathrm{C}$. After the cells grow adherently at the bottom of flask to form colonies, it was digested and separated with trypsin for seeding.

\subsubsection{Cell viability experiments}

The in vitro cytotoxicity was carried out by the quantitative MTT assay. Firstly, the films prepared under different electrodeposition conditions $(0.36-0.9 \mathrm{C})$ were cut into $8 \mathrm{~mm}$ diameter disks and sterilized by UV light overnight. The films were placed on the bottom of 24 well plate, and then cells were seeded with a density of $10^{4}$ cells per well. After incubating for a predetermined time, the cell activity of each group was carried out by MTT method. Cell viability was calculated by assuming $100 \%$ viability in the control set (media without films). 


\subsection{In vivo antimicrobial activity of $\mathrm{Cu}^{2+}$-Alg films}

All animal experiments adhered to the NIH guidelines for the care and use of laboratory animals (NIH Publication no. 85-23 Rev. 1985) and were approved by the Research Center for Laboratory Animals of Shanghai University of Traditional Chinese Medicine. Male Sprague Dawley (SD) rat (180-200 g) were divided into three groups: (i) $\left(\mathrm{Ca}^{2+}\right.$ $\mathrm{Alg})_{0.36 \mathrm{C}}$; (ii) $\left(\mathrm{Cu}^{2+}-\mathrm{Alg}\right)_{0.36 \mathrm{C}}$; (iii) commercial Ag dressing Biatain . Each group contains eight replicate samples, four samples were evaluated for 1 day and the rest were evaluated for 3 days. Two wounds with $1-2 \mathrm{~cm}$ in length were made on the back of each rat. All the sample films with $8 \mathrm{~mm}$ in diameter were individually pre-seeded with $10 \mu \mathrm{L}$ of inoculums containing $10^{8} \mathrm{CFU} / \mathrm{mL}$ of MRSA, and then air-dried. After that, each sample film was implanted into one incision. After 1 day and 3 days' implantation, the animals were euthanized by inhalant anesthetic and the bacteria on wound site were quantified by dilution plate assay. The wounds after 3 days' treatment were excised and fixed in $10 \%$ formaldehyde, then embedded in paraffin, cut into sections, and finally stained with $H \& E$ dye.

\subsection{Statistical analysis}

All data were expressed as mean and standard deviation (SD) and analyzed using one-way ANOVA with post hoc tests. Significance was set at $p<0.05(* * * p<0.001, * * p<$ $0.01, * p<0.05$ ), while $p>0.05$ was considered to be statistically non-significant.

\section{Results and discussions}

\subsection{Characterization of copper alginate films}

In this study, we used an anodic deposition strategy to fabricate $\mathrm{Cu}^{2+}$ - $\mathrm{Alg}$ films. Experimentally, $\mathrm{Cu}_{2}(\mathrm{OH})_{2} \mathrm{CO}_{3}$ powders $(0.5 \mathrm{wt} \%)$ were blended into a sodium alginate $(0.8 \mathrm{wt} \%)$ solution along with stirring for $5 \mathrm{~h}$. After being fully mixed, a three-electrode system was immersed into the electrolyte to electrodeposit materials using a constant current control for a predetermined time. After a few seconds, a uniform copper alginate hydrogel film formed in the anode surface. A self-supporting film was easily to be obtained by carefully peeling off the materials from the electrode. The corresponding dry film was obtained by extensive rinsing with ultrapure water and then freezedrying. $\left(\mathrm{Cu}^{2+}-\mathrm{Alg}\right) \mathrm{q}$ is used to denote the obtained film ( $\mathrm{q}$ indicates the consumed charge amount).

Figure 1a shows the photographs of $\mathrm{Cu}^{2+}$-Alg film prepared by electrodeposition using a constant current density of $2.67 \mathrm{~mA} / \mathrm{cm}^{2}$ for $90 \mathrm{~s}$. The total consumed charges are summed as $0.54 \mathrm{C}$. The left indicates the employed threeelectrode system immersed with $\mathrm{Cu}_{2}(\mathrm{OH})_{2} \mathrm{CO}_{3}$-Alginate electrolyte. The right upper indicates the freshly prepared $\left(\mathrm{Cu}^{2+}-\mathrm{Alg}\right)_{0.54 \mathrm{C}}$ film appearing a uniform light blue, which is due to the incorporation of $\mathrm{Cu}^{2+}$. The right lower shows a sponge-like morphology of freeze-dried $\left(\mathrm{Cu}^{2+}-\mathrm{Alg}\right)_{0.54 \mathrm{C}}$ film. The dry film was further used for morphological observation. SEM observation in Fig. 1b reveals many open pores with $\sim 135 \mu \mathrm{m}$ in diameter are distributed on film surface (Fig. S1 shows the histogram of pore size distribution), which are presumably generated by the released $\mathrm{CO}_{2}$ and $\mathrm{O}_{2}$ near the anode. The porosity from the interconnected pores was about $51.2 \%$, characterized by a wicking test. The uniform and porous structure might be capable to improve the water uptake and permeability of copper alginate films which are benefit for wound treatment.

The elemental analysis and compositional distribution of the dressings were further investigated by EDS mapping. Figure 1c shows that copper ions were successfully integrated into the $\left(\mathrm{Cu}^{2+}-\mathrm{Alg}\right)_{0.54 \mathrm{C}}$ film, with the content of 16.7\%. The images in Fig. 1d are elemental mappings of C, $\mathrm{O}$, and $\mathrm{Cu}$, respectively. The results prove the continuously and uniformly spatial distribution of $\mathrm{Cu}^{2+}$ within the dressing. Therefore, electrodeposition is a superior method in preparing uniform copper alginate materials within a short time.

\subsection{Continuous modulation of films' thickness and copper content}

Figure 2a illustrates the correlation between the resultant film thickness and the amount of consumed charges. The thickness of hydrated films was measured by electronic spiral micrometer and the thickness of dry films was measured via SEM imaging of the cross sections of freeze-dried films. It can be seen that with the increase of charges, the deposited film is thicker and it indicates a linear relationship between film thickness and charge transfer both in dry and hydrated state. In principle, the increased anode charges induce more free $\mathrm{Cu}^{2+}$ to be generated near the anode, which further cross-link and deposit sodium alginates, and eventually make the hydrogel film thicker.

Figure $2 \mathrm{~b}$ insert shows photos of the $\mathrm{Cu}^{2+}$-Alg hydrogel films electrodeposited under different charge conditions. All the hydrogel films with different charge conditions show the characteristic blue color of $\mathrm{Cu}^{2+}$, and the color is getting darker along with the increase of charge. This is a visual evidence to illustrate the relationship between $\mathrm{Cu}^{2+}$ and consumed charges.

In order to quantify the exact content of $\mathrm{Cu}^{2+}$ ions that were incorporated inside the alginate films, we first disintegrated $\mathrm{Cu}^{2+}$-Alg hydrogel film by competitively chelating $\mathrm{Cu}^{2+}$ with citrate ions and then performed an ICP-AES 
(a)

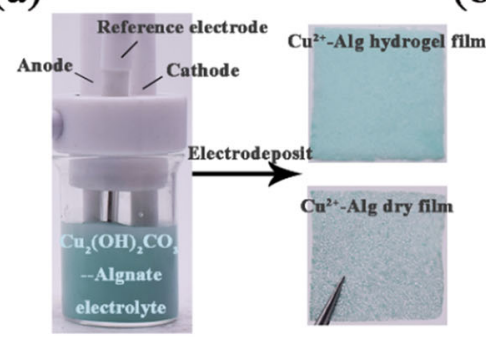

(d)

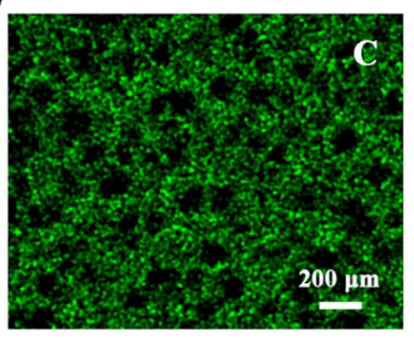

(b)
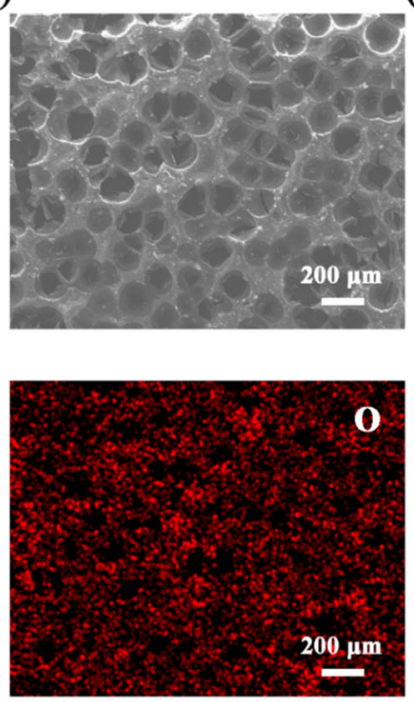

(c)
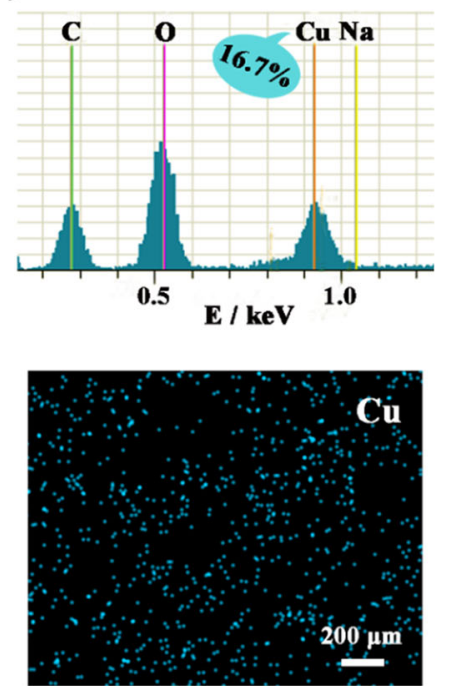

Fig. 1 a The photographs of gel and dry $\mathrm{Cu}^{2+}$-Alg films prepared by electrodeposition. $\mathbf{b}$ Surface SEM image of $\left(\mathrm{Cu}^{2+}-\mathrm{Alg}\right)_{0.54 \mathrm{C} \cdot} \mathbf{c} \mathrm{EDS}$ spectra of $\left(\mathrm{Cu}^{2+}-\mathrm{Alg}\right)_{0.54 \mathrm{C}}$. d EDS mapping of $\mathrm{C}, \mathrm{O}$, and $\mathrm{Cu}$ elements within the dressing, respectively

Fig. 2 The linear correlation between the film thickness (a) and copper contents $(\mathbf{b})$ with the consumed charges for $\mathrm{Cu}^{2+}-\mathrm{Alg}$ fabrication (a)

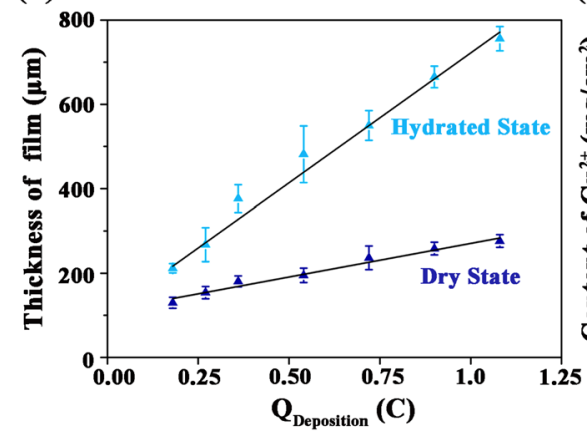

(b)

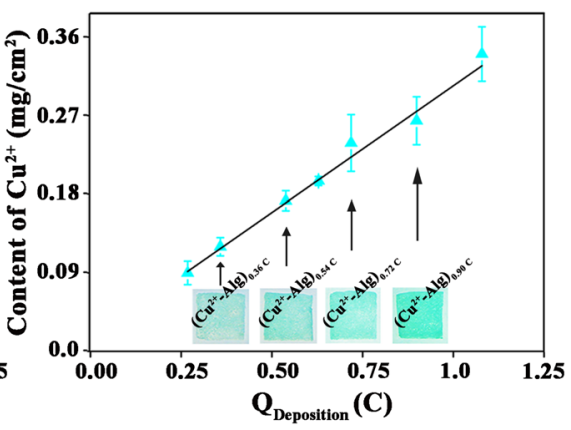

measurement to test the content of released $\mathrm{Cu}^{2+}$. As indicated by the plot in Fig. 2 b, the $\mathrm{Cu}^{2+}$ content and consumed charges have a linear relationship. It can be explained by the same mechanism as mentioned above: the amount of electricity consumed during the electrodeposition determines the amount of $\mathrm{H}^{+}$produced by the anode electrolysis, which further determines the $\mathrm{Cu}^{2+}$ generated by the reaction of $\mathrm{H}^{+}$ with suspended $\mathrm{Cu}_{2}(\mathrm{OH})_{2} \mathrm{CO}_{3}$ particles. Therefore, when the amount of electricity increases, more $\mathrm{H}^{+}$react with $\mathrm{Cu}_{2}$ $(\mathrm{OH})_{2} \mathrm{CO}_{3}$ particles to liberate more $\mathrm{Cu}^{2+}$ to construct the $\mathrm{Cu}^{2+}$-Alg film.

Taken together, these results reveal that $\mathrm{Cu}^{2+}$-Alg films can be continuously and controllably prepared with corresponding physical structure (thickness) and chemical composition (copper content) by changing electrodeposition parameters.

Besides, all above factors will further influence the films' mechanical properties. Figure $\mathrm{S} 2 \mathrm{a}-\mathrm{c}$ shows that with the imposed charge increase, the breaking strength of the films also increase, the group $\left(\mathrm{Cu}^{2+}-\mathrm{Alg}\right)_{1.08 \mathrm{C}}$ can reach about 3.94 MPa. While there is no big difference between the breaking tensile strain of different $\mathrm{Cu}^{2+}$-Alg films, which all are about $4 \%$.

\subsection{In vitro antimicrobial activity of $\mathrm{Cu}^{2+}-\mathrm{Alg}$ films}

$\mathrm{Cu}^{2+}$ is considered to possess a broad spectrum of antibacterial properties, so we believe that the $\mathrm{Cu}^{2+}$-Alg films obtained by electrodeposition also have strong antibacterial activity.

To examine the antimicrobial activities of our films, $S$. aureus and E. coli were used in these antimicrobial experiments as gram-positive bacteria model and gramnegative bacteria model, respectively. We placed the film $\left(\mathrm{Cu}^{2+}-\mathrm{Alg}\right)_{0.54 \mathrm{C}}$ in a 24 well plate with bacteria at a concentration of $10^{7} \mathrm{CFU} / \mathrm{mL}$. Then, the antimicrobial activity 
was systematically evaluated after incubation in a $37^{\circ} \mathrm{C}$ bacterial incubator for 0.5 and $10 \mathrm{~h}$. In this study, a commercial Alginate Ag dressing (Biatain ${ }^{\circ}$ ) was used as the positive control group and the blank well plate was set as the negative control group. The commercial Alginate $\mathrm{Ag}$ dressing (Biatain ${ }^{\bullet}$ ) is composed of calcium alginate, carboxymethyl cellulose sodium, polyethylene glycol, and silver ion compound (zirconium sodium phosphate containing silver), which can release silver ions to perform the antimicrobial function in the presence of wound exudate when covered to the wound surface [49].

At first, we performed plate counting to assess bacterial viability as illustrated in Fig. 3a. The upper images show $\left(\mathrm{Cu}^{2+}-\mathrm{Alg}\right)_{0.54 \mathrm{C}}$ performed a lower plate count of S. aureus, indicating the strongest antimicrobial activities at $0.5 \mathrm{~h}$. After prolonging the incubation time to $10 \mathrm{~h}$, it can be seen that the plate counts of $\left(\mathrm{Cu}^{2+}-\mathrm{Alg}\right)_{0.54 \mathrm{C}}$ and the Ag dressing were both significantly reduced compared to the blank control. The lower photographs in Fig. 3a reveals that $E$. coli responded similarly to $\left(\mathrm{Cu}^{2+}-\mathrm{Alg}\right)_{0.54 \mathrm{C}}$ film and $\mathrm{Ag}$ dressing.

Quantification of these results are presented at the right in Fig. 3b, c. The results show that after incubation for $0.5 \mathrm{~h}$, the $\left(\mathrm{Cu}^{2+}-\mathrm{Alg}\right)_{0.54 \mathrm{C}}$ dressing performed a good antibacterial effect on both bacteria, with the ratio of $76 \%$ and $90 \%$ respectively, while the killing efficiency of Ag dressing were less than $10 \%$. After the incubation time was extended to $10 \mathrm{~h}$, both $\left(\mathrm{Cu}^{2+}-\mathrm{Alg}\right)_{0.54 \mathrm{C}}$ film and $\mathrm{Ag}$ - dressing's bactericidal rate reached $99.9 \%$, exhibiting comparable antibacterial abilities. This result illustrates that the $\left(\mathrm{Cu}^{2+}-\mathrm{Alg}\right)_{0.54 \mathrm{C}}$ film has a faster working time than commercial $\mathrm{Ag}$ dressing, which is essential for preventing the infected wound from deteriorating [50]. It might be ascribed to the faster-releasing speed of copper ions comparing to silver elements from their corresponsive polymer matrixes, which results in a distinct cell response at the early stage.

We further compared the antibacterial effect of $\mathrm{Cu}^{2+}$-Alg films prepared under different conditions. Three groups $\left(\mathrm{Cu}^{2+}-\mathrm{Alg}\right)_{0.36 \mathrm{C}},\left(\mathrm{Cu}^{2+}-\mathrm{Alg}\right)_{0.54 \mathrm{C}},\left(\mathrm{Cu}^{2+}-\mathrm{Alg}\right)_{0.72 \mathrm{C}}$ were used to incubate with $E$. coli for $10 \mathrm{~h}$, the results are shown in Fig. 3d, e. It can be seen that $\left(\mathrm{Cu}^{2+}-\mathrm{Alg}\right)_{0.54 \mathrm{C}}$ and $\left(\mathrm{Cu}^{2+}\right.$ $\mathrm{Alg})_{0.72 \mathrm{C}}$ showed an extremely high bactericidal rate of $99.9 \%$ against $E$. coli, while the killing efficiency of $\left(\mathrm{Cu}^{2+}-\right.$ $\mathrm{Alg})_{0.36 \mathrm{C}}$ reached to $90 \%$, which was lower than the former two groups. This can be explained by the relatively lowered $\mathrm{Cu}^{2+}$ content in $\left(\mathrm{Cu}^{2+}-\mathrm{Alg}\right)_{0.36 \mathrm{C}}$ (referring to Fig. $2 \mathrm{~b}$ ).

\subsection{Antibacterial mechanism}

Next, we performed several studies to reveal the antibacterial mechanism of the $\mathrm{Cu}^{2+}$-Alg films. An inhibition zone assay was initiated to determine the contribution of $\mathrm{Cu}^{2+}$ for bacterial inhibition. In these experiments, trimmed film samples were placed onto the surface of an agar plate to make it in close contact with bacteria, and incubated at $37^{\circ} \mathrm{C}$

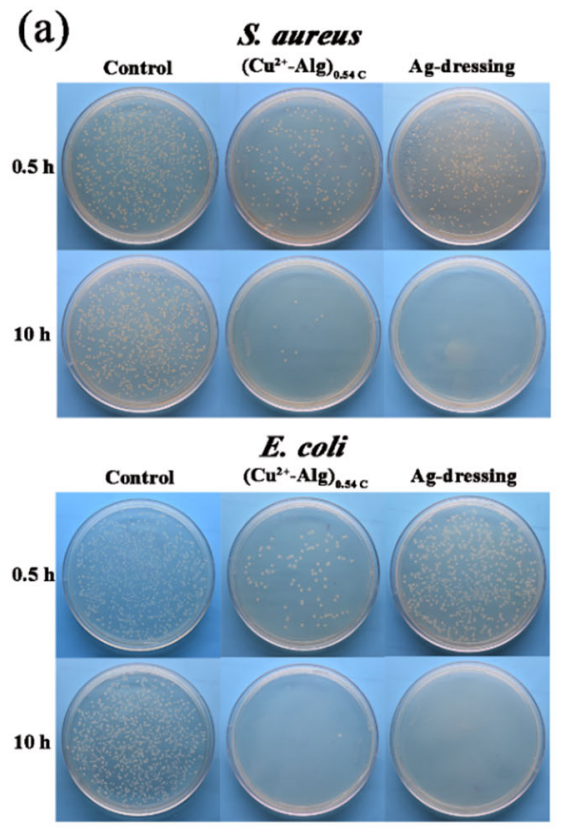

(b)

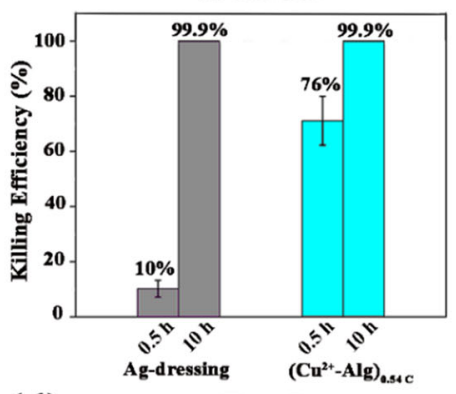

(d)

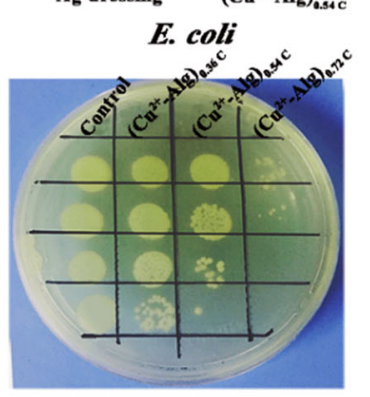

(c)
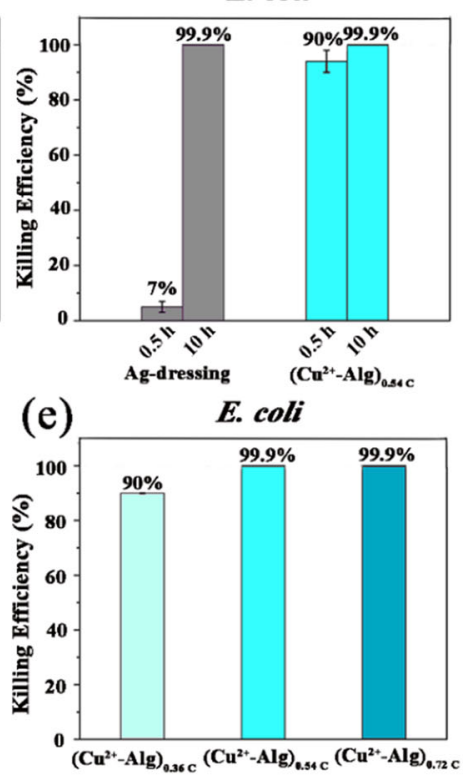

Fig. 3 In vitro antimicrobial activities. a Photographs of $S$. aureus and E. coli colonies on the ager plate after incubation with different samples and gradient dilution. b Bacterial killing efficiency of $\left(\mathrm{Cu}^{2+}\right.$ $\mathrm{Alg})_{0.54 \mathrm{C}}$ and commercial $\mathrm{Ag}$ dressing against $S$. aureus and $\mathbf{c}$ E. coli. d Photographs of $E$. coli colonies on the ager plate after incubation with $\mathrm{Cu}^{2+}-\mathrm{Alg}$ films prepared by different charge conditions and gradient dilution. e Bacterial killing efficiency of electrodeposited $\mathrm{Cu}^{2+}$-Alg films prepared by different charge conditions. Bacteria incubated in the blank well plate were set as the control 
(a)

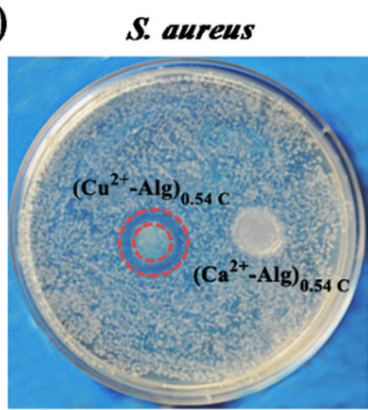

(c)

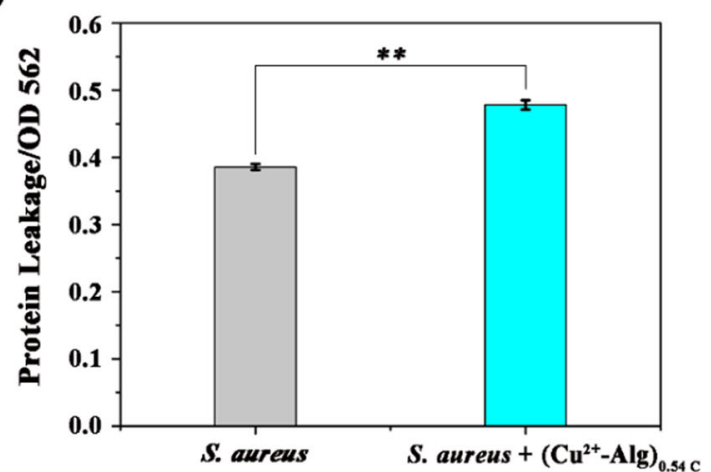

(e)
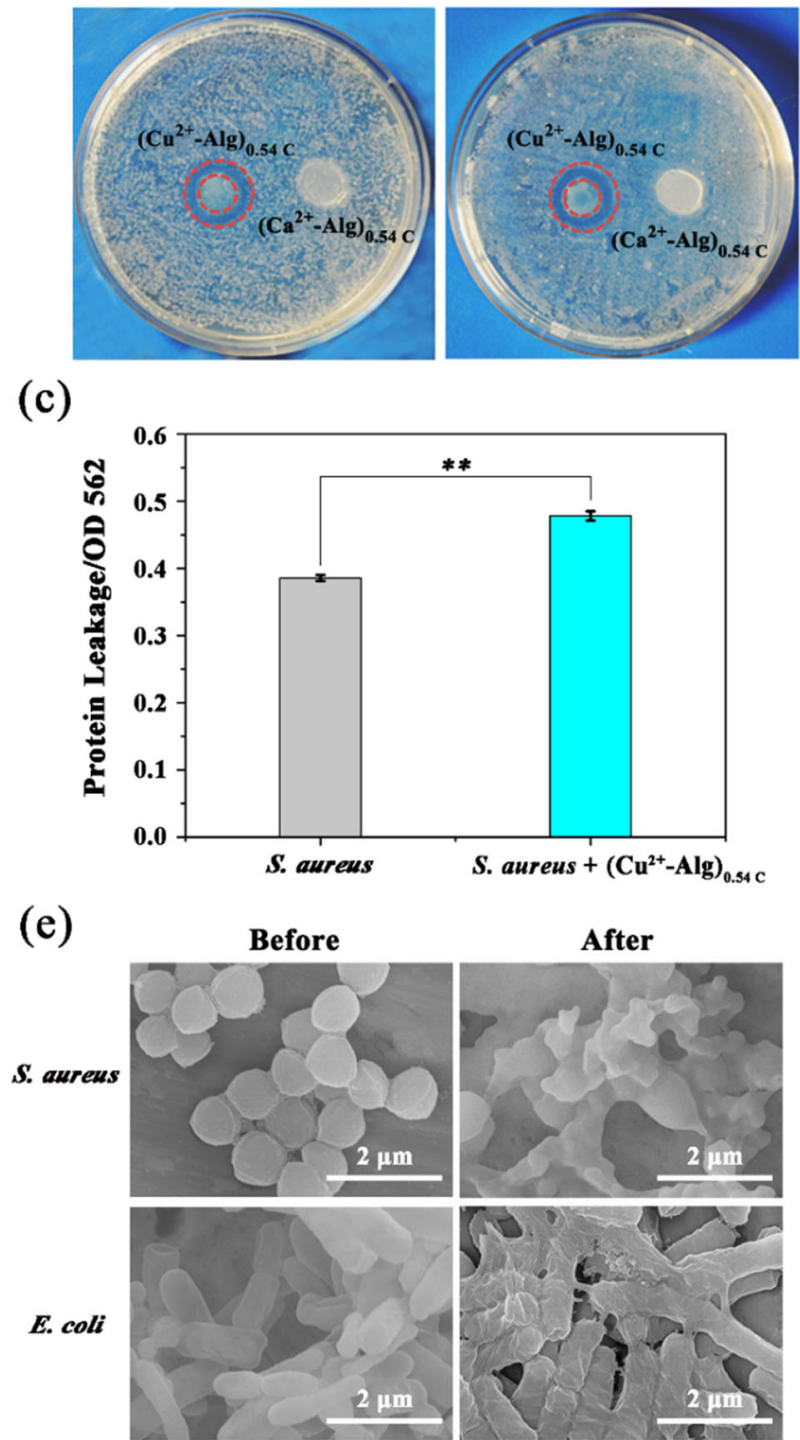

(b)

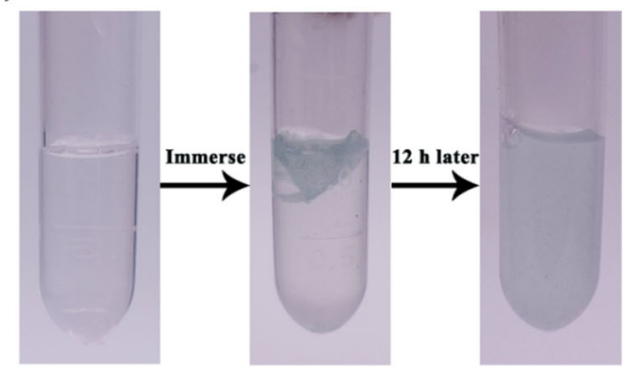

(d)

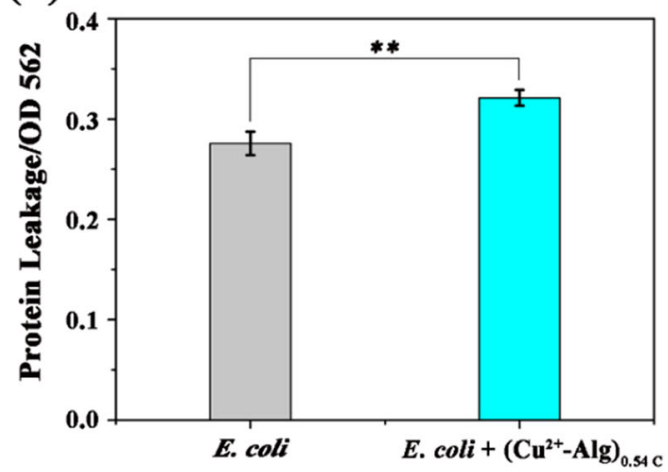

(f)

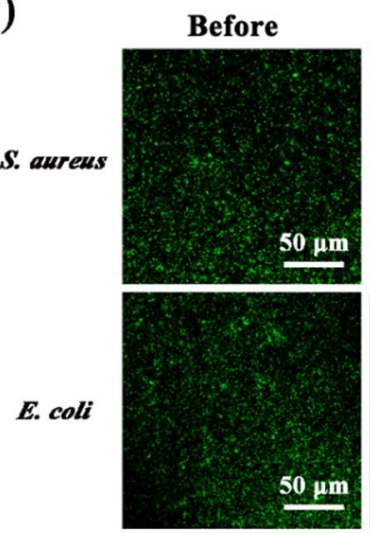

After

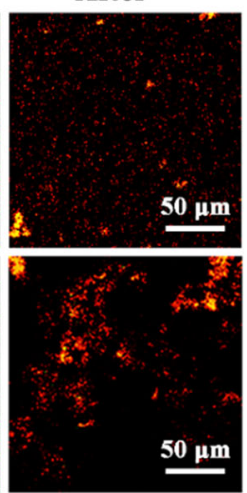

Fig. 4 a $\left(\mathrm{Cu}^{2+}-\mathrm{Alg}\right)_{0.54 \mathrm{C}}$ film generates a zone of bacteria inhibition in an agar plate assay. b The decomposing process of $\left(\mathrm{Cu}^{2+}-\mathrm{Alg}\right)_{0.54 \mathrm{C}}$ film in PBS buffer. c Protein leakage of and $S$. aureus. d E. coli after incubation with $\left(\mathrm{Cu}^{2+}-\mathrm{Alg}\right)_{0.54 \mathrm{C}}$ film for $10 \mathrm{~h}$. The higher value of OD 562 indicates higher protein leakage, which originates from cell

for $12 \mathrm{~h}$. Here we use the electrodeposited $\left(\mathrm{Ca}^{2+}-\mathrm{Alg}\right)_{0.54 \mathrm{C}}$ film reported in our previous work as the negative control group. The results in Fig. 4a indicate that after contact with S. aureus and E. coli, $\left(\mathrm{Cu}^{2+}-\mathrm{Alg}\right)_{0.54 \mathrm{C}}$ created an obvious growth inhibition-zone, which was attributed to the release of diffusible $\mathrm{Cu}^{2+}$. No inhibition-zone was observed for the control films $\left(\left(\mathrm{Ca}^{2+}-\mathrm{Alg}\right)_{0.54 \mathrm{C}}\right)$. We then examined the $\left(\mathrm{Cu}^{2+}-\mathrm{Alg}\right)_{0.54 \mathrm{C}}$ film's decomposing in PBS buffer, as shown in Fig. 4b. It can be seen that the film collapsed completely after $12 \mathrm{~h}$ soaking and the solution became light blue, demonstrating a $\mathrm{Cu}^{2+}$ diffusion determined antibacterial activity. Mechanistically, it is believed that $\mathrm{Cu}^{2+}$ kills membrane damage. e SEM images of E. coli and S. aureus before and after film treatment. Scale bar is $2 \mu \mathrm{m}$. $\mathbf{f}$ Live and dead staining images of $E$. coli and $S$. aureus before and after film treatment. Green color indicates live and dead bacteria; red color indicates dead bacteria. Scale bar is $50 \mu \mathrm{m}$

bacteria firstly through damage or destruction of the cell membrane [51-53], and such damage is assessed by measuring protein leakage associated with such permeability changes [54, 55]. According to Fig. 4c, d, after incubation with $\left(\mathrm{Cu}^{2+}-\mathrm{Alg}\right)_{0.54 \mathrm{C}}$ film for $10 \mathrm{~h}, S$. aureus and $E$. coli exhibited statistically higher protein leakage compared to the control group, demonstrating that the bacterial membrane has experienced a severe damage.

We then examined if incubation with $\left(\mathrm{Cu}^{2+}-\mathrm{Alg}\right)_{0.54 \mathrm{C}}$ film induced significant morphological changes to bacteria. The SEM images in Fig. 4e show that the original shape of $S$. aureus was spherical, and E. coli had a rod-like shape, 


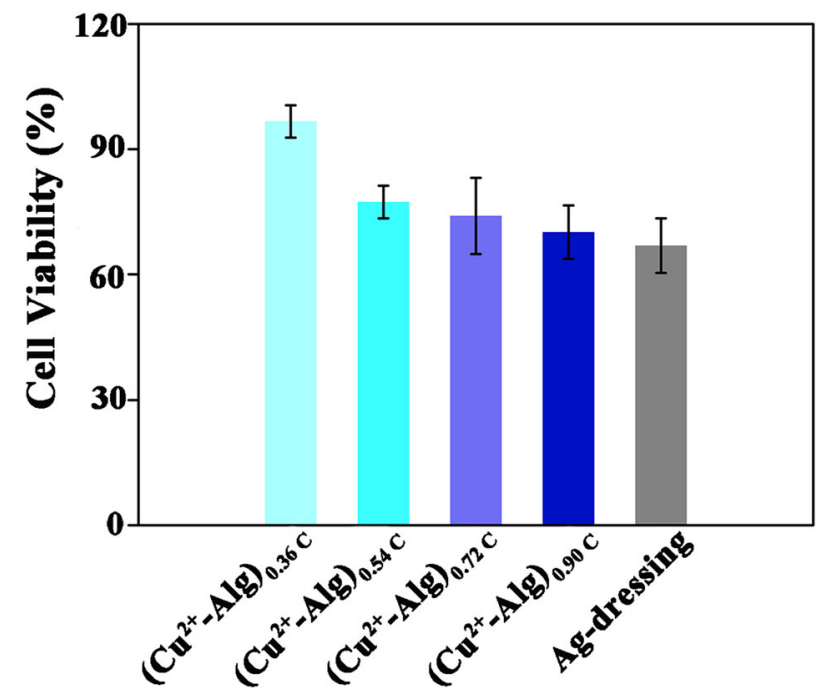

Fig. 5 The biocompatibility estimation of films using a MTT viability assay. HUVECs cells were cultured in the presence of different films for 1 day. HUVECs cell viability assays provide evidence that all the $\mathrm{Cu}^{2+}$-Alg films have comparable or better cell compatibility than commercial Ag dressing

both in a normal growth state. After the treatment with $\left(\mathrm{Cu}^{2+}-\mathrm{Alg}\right)_{0.54 \mathrm{C}}$ films, the morphology of the bacteria changed greatly, with disruption of the cellular structure and the loss of original appearance. This result further confirms the conclusion that $\mathrm{Cu}^{2+}$ can cause membrane disruption and structural deformation of bacteria.

Finally, a live (green)/dead (red) staining assay was applied in visual observation of bacterial state. In this experiment, the bacteria were incubated for $10 \mathrm{~h}$ with $\left(\mathrm{Cu}^{2+}-\mathrm{Alg}\right)_{0.54 \mathrm{C}}$, before and after which they were stained for viability using the fluorescence dyes SYTO 9 and PI. The confocal images in Fig. 4f show a large number of green (viable) bacteria before film treatment, while a large number of yellow or red bacteria were observed after incubation with $\left(\mathrm{Cu}^{2+}-\mathrm{Alg}\right)_{0.54 \mathrm{C}}$ films, demonstrating that both bacteria have almost died [56].

In summary, the results in both Fig. 3 and Fig. 4 exhibit the great antibacterial effect of electrodeposited $\mathrm{Cu}^{2+}$-Alg films both against gram-positive and gram-negative bacteria through releasing $\mathrm{Cu}^{2+}$ to destruct the cell membrane of bacteria.

\subsection{Cell viability of $\mathrm{Cu}^{2+}-\mathrm{Alg}$ films}

Biocompatibility is one of the basic requirements for biomedical materials for wound treatment. To study the cytotoxicity of prepared $\mathrm{Cu}^{2+}$-Alg films, HUVECs were cocultured with different $\mathrm{Cu}^{2+}$-Alg films for $24 \mathrm{~h}$. An MTT assay was performed to evaluate the cell viability.

Figure 5 indicated that the viabilities of cells treated with $\left(\mathrm{Cu}^{2+}-\mathrm{Alg}\right)_{0.36 \mathrm{C}},\left(\mathrm{Cu}^{2+}-\mathrm{Alg}\right)_{0.54 \mathrm{C}},\left(\mathrm{Cu}^{2+}-\mathrm{Alg}\right)_{0.72 \mathrm{C}}$,
$\left(\mathrm{Cu}^{2+}-\mathrm{Alg}\right)_{0.90 \mathrm{C}}$, and Ag-dressing were: $97,77,74,70$, $68 \%$, respectively. And all of these $\mathrm{Cu}^{2+}$-Alg films behaved comparable or better cell compatibility than commercial Ag dressing. Varying consumed charges can effectively modulate the biocompatibility of $\mathrm{Cu}^{2+}$-Alg films. Remarkably, the electrodeposited $\mathrm{Cu}^{2+}$-Alg films can be adjusted to possess both high antimicrobial capability and good biocompatibility just by charge transfer $(\mathrm{Q})$.

\subsection{In vivo antimicrobial activity of $\mathrm{Cu}^{2+}-\mathrm{Alg}$ films}

To evaluate the in vivo antimicrobial activity, we used an infected SD rat model in which bacteria contaminated films were implanted subcutaneously. MRSA was employed as a model bacterium for this study since it is responsible for several difficult-to-treat infections in humans. Three groups were set up in the experiment: $\left(\mathrm{Ca}^{2+}-\mathrm{Alg}\right)_{0.36 \mathrm{C}},\left(\mathrm{Cu}^{2+}-\mathrm{Alg}\right)_{0.36 \mathrm{C}}$, and commercial silver dressing. Two $1-2 \mathrm{~cm}$ length incisions were created in the dorsum of each rat, then the films were implanted into the wound site after seeding $10 \mu \mathrm{L}$ of MRSA $\left(10^{8} \mathrm{CFU} / \mathrm{mL}\right)$. All groups were sutured after material implantation.

1 day and 3 days after surgery, the animals were sacrificed and wounds were reopened. The infection state was photographed as shown in Fig. 6a. It can be seen that after 1 day and 3 days, the wounds implanted with the $\left(\mathrm{Cu}^{2+}\right.$ $\mathrm{Alg})_{0.36 \mathrm{C}}$ film and $\mathrm{Ag}$ dressing presented a slight suppuration, while the control wound treated with $\left(\mathrm{Ca}^{2+}-\mathrm{Alg}\right)_{0.36 \mathrm{C}}$ had obvious inflammation and serious suppuration, indicating that the wound was severely infected.

Each wound site was wiped with cotton swabs to collect bacteria, and diluted plate counts were performed to evaluate the antibacterial efficiency (Fig. 6b). The results in Fig. $6 \mathrm{c}$ illustrate that after 1 day and 3 days' implantation, the considerably lower bacterial colonies were observed in the incision implanted with $\left(\mathrm{Cu}^{2+}-\mathrm{Alg}\right)_{0.36 \mathrm{C}}$, verifying a successful inhibition on the microbe growth that can be comparable with commercial silver dressing. Statistically, we observed an average over 1-Log reduction of bacterial number in the implantation site of $\left(\mathrm{Cu}^{2+}-\mathrm{Alg}\right)_{0.36 \mathrm{C}}$ in comparison with the $\left(\mathrm{Ca}^{2+}-\mathrm{Alg}\right)_{0.36 \mathrm{C}}$ group.

Histological evaluation of the adjacent skin tissue after 3 days' film implantation was also carried out by hematoxylin and eosin stained sections (H\&E staining). In Fig. 6d, it is obvious that a large number of inflammatory cells existed in the control groups $\left(\left(\mathrm{Ca}^{2+}-\mathrm{Alg}\right)\right.$ 0.36C) implying that the possible infection and immune response occurred. Instead, a significant decrease of inflammatory cells is observed in the $\left(\mathrm{Cu}^{2+}-\mathrm{Alg}\right)_{0.36 \mathrm{C}}$ and Ag-dressing groups. These results verified the strong antibacterial capability and good tissue compatibility of copper alginate films in vivo. 


\section{(a)}
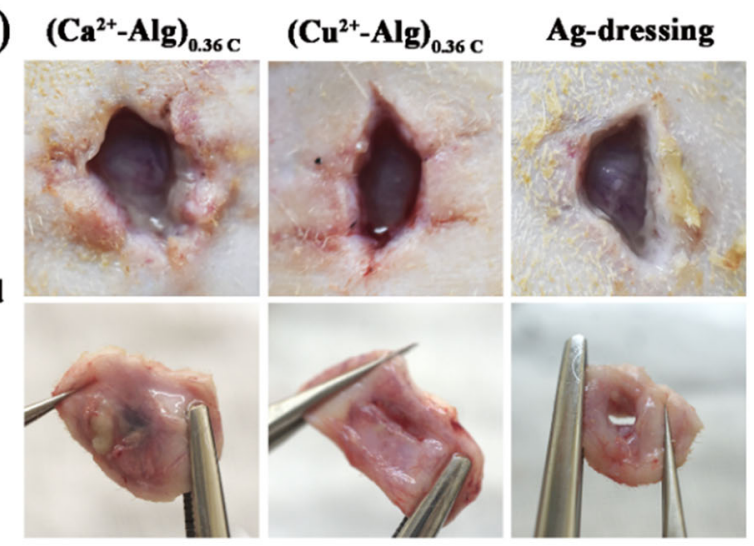

(b)
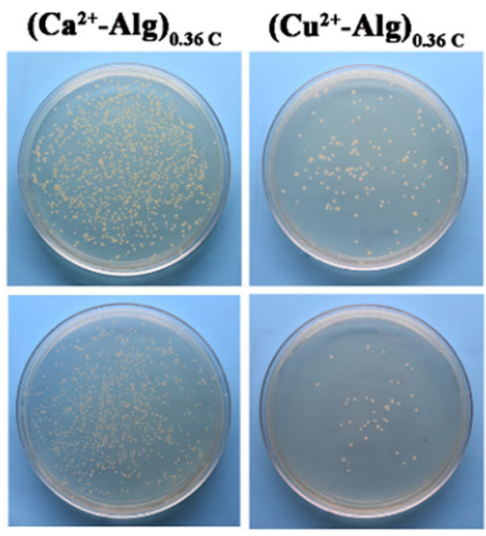

(d)

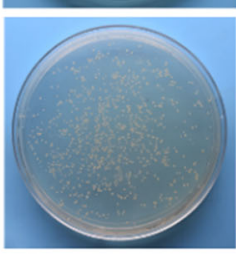

3 d

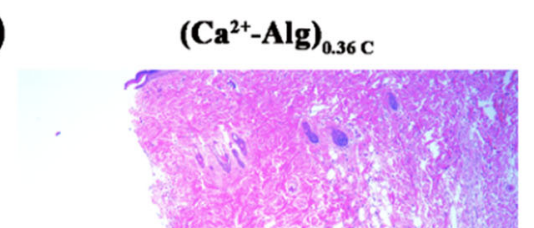

3 d

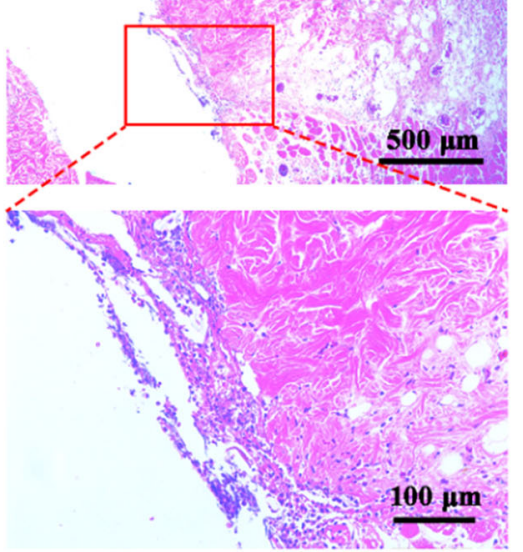

Fig. 6 In vivo antimicrobial studies by employing an infected SD rat model. a Photographs of re-opened incisions with different treatments after 1 day and 3 days. b Exudate bacterial plate counting and c

\section{Conclusions}

In summary, we report a functional antibacterial $\mathrm{Cu}^{2+}-\mathrm{Alg}$ dressing prepared by a novel electro-fabrication methodology, which is much more convenient, efficient, and

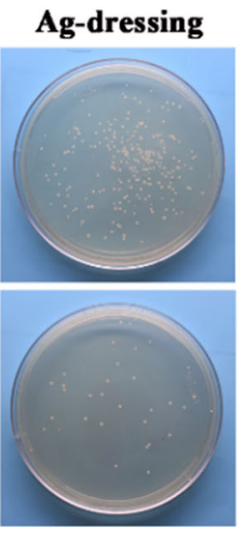

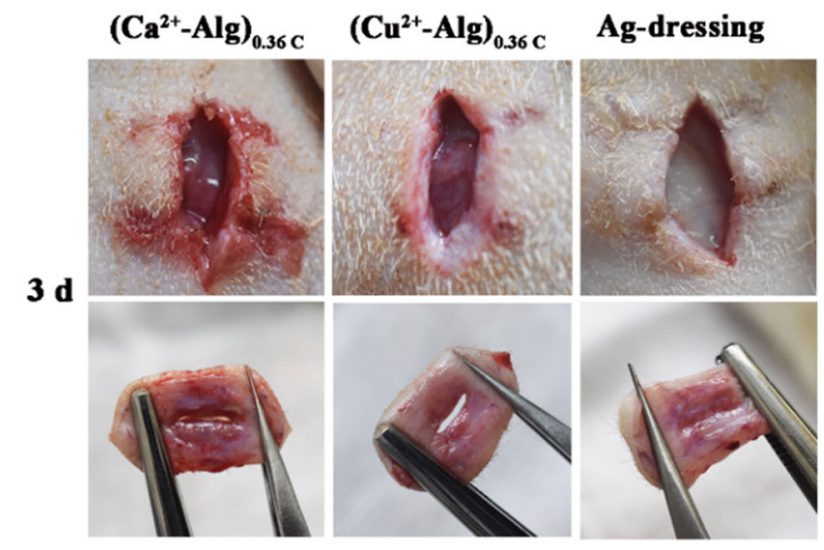

(c)

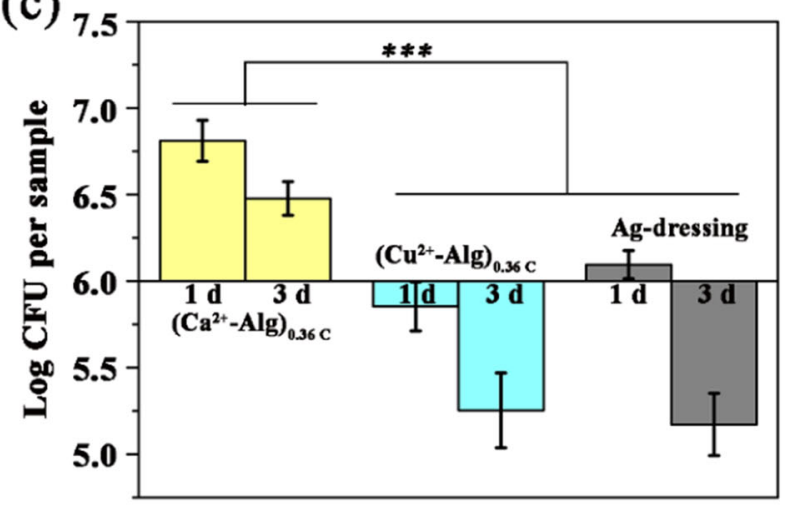

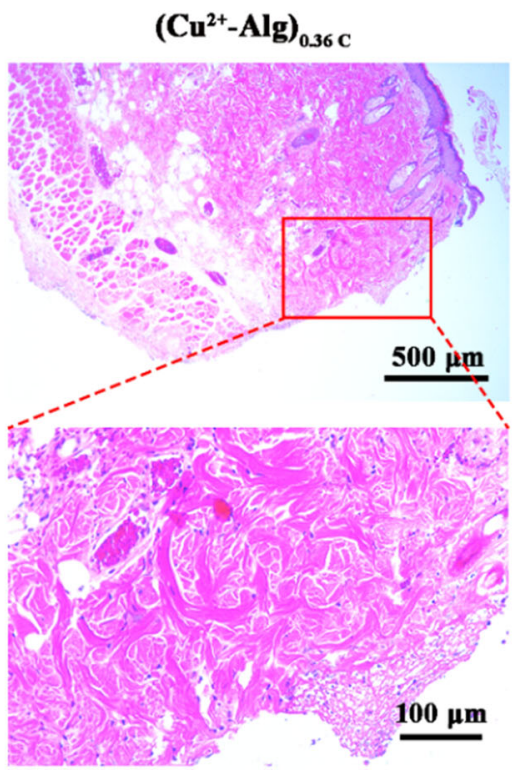

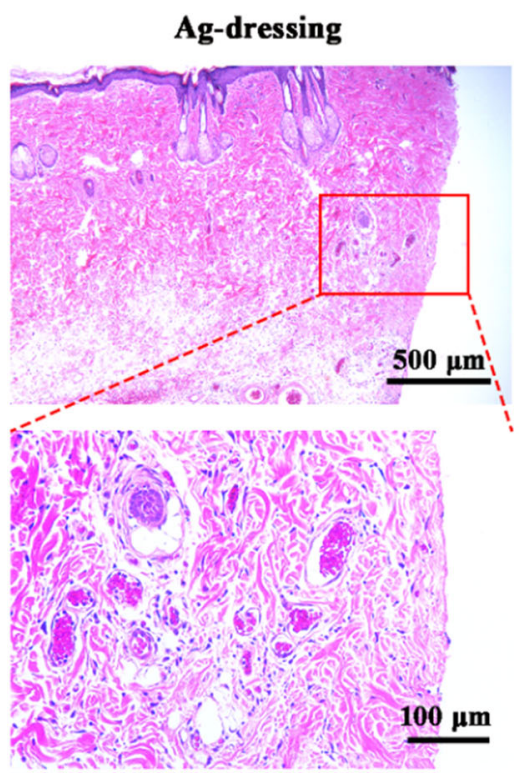

quantitative summary plot at day 1 and day 3 postoperatively. d Histological analysis of implantation sites after 3 days' treatment. Scale bar is 500 and $100 \mu \mathrm{m}$, respectively

controllable compared to the traditional strategies. The generated film possesses a porous structure and excellent uniformity. More importantly, the $\mathrm{Cu}^{2+}$ content and thickness of the film can be continuously regulated by adjusting the electricity consumption during fabrication. At the same 
time, the $\mathrm{Cu}^{2+}$-Alg films have strong antimicrobial activities both in vitro and in vivo through releasing $\mathrm{Cu}^{2+}$ to destroy the cell membrane of bacteria, which was equivalent to commercial Ag dressings, but has a shorter onset time. The cytotoxicity and antibacterial efficiency of $\mathrm{Cu}^{2+}$-Alg dressings were both positively related to $\mathrm{Cu}^{2+}$ content. Therefore, the controllability of electro-fabrication makes it possible to endow $\mathrm{Cu}^{2+}$-Alg dressings with both high antimicrobial capability and good biocompatibility just by adjusting charge transfer.

In view of the controllability, uniformity and excellent antibacterial properties of the electrodeposited $\mathrm{Cu}^{2+}$-Alg film, we envision this film has great potential value in the field of antibacterial dressings.

Acknowledgements This research was supported by the National Natural Science Foundation of China (31922041, 51621002, and 11932012), the Science and Technology Innovation Project of Shanghai Science and Technology Committee (18441908300), and the Fundamental Research Funds for the Central Universities (SLD00202006, JKVD12001032, JKVD12001002).

\section{Compliance with ethical standards}

Conflict of interest The authors declare no competing interests.

Ethical approval All animal experiments adhered to the NIH guidelines for the care and use of laboratory animals (NIH Publication no. 85-23 Rev. 1985) and were approved by the Research Center for Laboratory Animals of Shanghai University of Traditional Chinese Medicine.

Publisher's note Springer Nature remains neutral with regard to jurisdictional claims in published maps and institutional affiliations.

Open Access This article is licensed under a Creative Commons Attribution 4.0 International License, which permits use, sharing, adaptation, distribution and reproduction in any medium or format, as long as you give appropriate credit to the original author(s) and the source, provide a link to the Creative Commons license, and indicate if changes were made. The images or other third party material in this article are included in the article's Creative Commons license, unless indicated otherwise in a credit line to the material. If material is not included in the article's Creative Commons license and your intended use is not permitted by statutory regulation or exceeds the permitted use, you will need to obtain permission directly from the copyright holder. To view a copy of this license, visit http://creativecommons. org/licenses/by/4.0/.

\section{References}

1. Gould LJ, Fulton AT. Wound healing in older adults. Rhode Isl Med J. 2016;99:34-6.

2. Sgonc R, Gruber J. Age-related aspects of cutaneous wound healing: a mini-review. Gerontology. 2013;59:159-64. https://doi. org/10.1159/000342344.

3. Singer AJ, Clark RAF. Mechanisms of disease—cutaneous wound healing. N. Engl J Med. 1999;341:738-46. https://doi.org/10. 1056/nejm199909023411006.
4. Akbik D, Ghadiri M, Chrzanowski W, Rohanizadeh R. Curcumin as a wound healing agent. Life Sci. 2014;116:1-7. https://doi.org/ 10.1016/j.lfs.2014.08.016.

5. Humphreys G, Lee GL, Percival SL, McBain AJ. Combinatorial activities of ionic silver and sodium hexametaphosphate against microorganisms associated with chronic wounds. J Antimicrobial Chemother. 2011;66:2556-61. https://doi.org/10.1093/jac/dkr350.

6. Clinton L, Carter T. Chronic wound biofilms: pathogenesis and potential therapies. Labmedicine. 2015;46:277-84. https://doi.org/ 10.1309/lmbnswkui4jpn7so.

7. Kirketerp-Moller K, Jensen PO, Fazli M, Madsen KG, Pedersen J, Moser C. et al. Distribution, organization, and ecology of bacteria in chronic wounds. J Clin Microbiol. 2008;46:2717-22. https:// doi.org/10.1128/jcm.00501-08.

8. DeLeo FR, Otto M, Kreiswirth BN, Chambers HF. Communityassociated meticillin-resistant Staphylococcus aureus. Lancet. 2010;375:1557-68. https://doi.org/10.1016/s0140-6736(09)61999-1.

9. Datta R, Huang SS. Risk of infection and death due to methicillinresistant Staphylococcus aureus in long-term carriers. Clin Infect Dis. 2008;47:176-81. https://doi.org/10.1086/589241.

10. Tong SYC, Davis JS, Eichenberger E, Holland TL, Fowler VG,Jr. Staphylococcus aureus infections: epidemiology, pathophysiology, clinical manifestations, and management. Clin Microbiol Rev. 2015;28:603-61. https://doi.org/10.1128/cmr.00134-14.

11. Simoes D, Miguel SP, Ribeiro MP, Coutinho P, Mendonca AG, Correia IJ. Recent advances on antimicrobial wound dressing: a review. Eur J Pharmaceutics Biopharmaceutics. 2018;127:130-41. https://doi.org/10.1016/j.ejpb.2018.02.022.

12. Ding X, Duan S, Ding X, Liu R, Xu F-J. Versatile antibacterial materials: an emerging arsenal for combatting bacterial pathogens. advanced functional materials. 2018;28. https://doi.org/10.1002/a dfm. 201802140.

13. Aderibigbe BA, Buyana B. Alginate in wound dressings. Pharmaceutics. 2018;10. https://doi.org/10.3390/pharmaceutics10020042.

14. Lee KY, Mooney DJ. Alginate: properties and biomedical applications. Prog Polym Sci. 2012;37:106-26. https://doi.org/10. 1016/j.progpolymsci.2011.06.003.

15. Sood A, Granick MS, Tomaselli NL. Wound dressings and comparative effectiveness data. Adv Wound Care. 2014;3:511-29.

16. Liu X, Liu H, Qu X, Lei M, Zhang C, Hong H, et al. Electrical signals triggered controllable formation of calcium-alginate film for wound treatment. J Mater Sci-Mater Med. 2017;28. https://doi. org/10.1007/s10856-017-5956-x.

17. Augst AD, Kong HJ, Mooney DJ. Alginate hydrogels as biomaterials. Macromol Biosci. 2006;6:623-33. https://doi.org/10.1002/ mabi.200600069.

18. Tawfik SM, Hefni HH. Synthesis and antimicrobial activity of polysaccharide alginate derived cationic surfactant-metal(II) complexes. Int J Biol Macromol. 2016;82:562-72. https://doi.org/ 10.1016/j.ijbiomac.2015.09.043.

19. Smidsrod O, Haug A. Dependence upon the gel-sol state of the ion-exchange properties of alginates. Acta Chem Scandinavica. 1972;26:2063-74. https://doi.org/10.3891/acta.chem.scand.262063.

20. Braccini I, Perez S. Molecular basis of $\mathrm{Ca} 2+$-induced gelation in alginates and pectins: the egg-box model revisited. Biomacromolecules. 2001;2:1089-96. https://doi.org/10.1021/bm010008g.

21. Linder MC, Hazegh-Azam M. Copper biochemistry and molecular biology. Am J Clin Nutr. 1996;63:797S-811S.

22. Michels H, Moran W, Michel J. Antimicrobial properties of copper alloy surfaces, with a focus on hospital-acquired infections. Int J Metalcasting. 2008;2:47-56. https://doi.org/10.1007/ bf03355432. 
23. Revenko MD, Prisacari VI, Dizdari AV, Stratulat EF, Corja ID, Proca LM. Synthesis, antibacterial, and antifungal activities of 8-quinolinealdehyde chalcogensemicarbazones and their copper (II) complexes. Pharm Chem J. 2011;45:351-4. https://doi.org/10. 1007/s11094-011-0631-x.

24. Li J, Zhai D, Lv F, Yu Q, Ma H, Yin J. et al. Preparation of copper-containing bioactive glass/eggshell membrane nanocomposites for improving angiogenesis, antibacterial activity and wound healing. Acta Biomaterialia. 2016;36:254-66. https://doi. org/10.1016/j.actbio.2016.03.011.

25. Chatterjee AK, Chakraborty R, Basu T. Mechanism of antibacterial activity of copper nanoparticles. Nanotechnology. 2014;25. https://doi.org/10.1088/0957-4484/25/13/135101.

26. Michels HT, Anderson DG. Antimicrobial regulatory efficacy testing of solid copper alloy surfaces in the USA. In: Collery P, Maymard I, Theophanides T, Khassanova L, Collery T, editors. Metal Ions in Biology and Medicine, Vol 10. Metal Ions in Biology and Medicine, 2008. pp185-190.

27. Meghana S, Kabra P, Chakraborty S, Padmavathy N. Understanding the pathway of antibacterial activity of copper oxide nanoparticles. Rsc Adv. 2015;5:12293-9. https://doi.org/10.1039/ c4ra12163e.

28. Mourino V, Pablo Cattalini J, Boccaccini AR. Metallic ions as therapeutic agents in tissue engineering scaffolds: an overview of their biological applications and strategies for new developments. J R Soc Interface. 2012;9:401-19. https://doi.org/10.1098/rsif. 2011.0611.

29. Turnlund JR, Keyes WR, Peiffer GL, Scott KC. Copper absorption, excretion, and retention by young men consuming low dietary copper determined by using the stable isotope $65 \mathrm{Cu}$. Am J Clin Nutr. 1998;67:1219-25.

30. Tapiero H, Townsend DM, Tew KD. Trace elements in human physiology and pathology. Copp Biomed Pharmacother. 2003;57:386-98. https://doi.org/10.1016/s0753-3322(03)00012-x.

31. Klinkajon W, Supaphol P. Novel copper (II) alginate hydrogels and their potential for use as anti-bacterial wound dressings. Biomed Mater. 2014;9. https://doi.org/10.1088/1748-6041/9/4/ 045008.

32. Grace M, Chand N, Bajpai SK. Copper Alginate-Cotton Cellulose (CACC) Fibers with Excellent Antibacterial Properties. J Engineered Fibers Fabr. 2009;4:24-35.

33. Madzovska-Malagurski I, Vukasinovic-Sekulic M, Kostic D, Levic S. Towards antimicrobial yet bioactive $\mathrm{Cu}$-alginate hydrogels. Biomed Mater. 2016;11. https://doi.org/10.1088/1748-6041/ $11 / 3 / 035015$.

34. Zheng H. Interaction mechanism in sol-gel transition of alginate solutions by addition of divalent cations. Carbohydr Res. 1997;302:97-101. https://doi.org/10.1016/s0008-6215(97)00114-6.

35. Goh $\mathrm{CH}$, Heng PWS, Chan LW. Cross-linker and non-gelling $\mathrm{Na}+$ effects on multi-functional alginate dressings. Carbohydr Polym. 2012;87:1796-802. https://doi.org/10.1016/j.carbpol. 2011.09.097.

36. Li J, Wu S, Kim E, Yuan K, Liu H, Liu C, et al. Electrobiofabrication: electrically based fabrication with biologically derived materials. Biofabrication. 2019;11. https://doi.org/10. 1088/1758-5090/ab06ea.

37. Wu S, Yan K, Li J, Huynh RN, Raub CB, Shen J, et al. Electrical cuing of chitosan's mesoscale organization. React Funct Polym. 2020;148. https://doi.org/10.1016/j.reactfunctpolym.2020.104492.

38. Avcu E, Bastan FE, Abdullah HZ, Rehman MAU, Avcu YY, Boccaccini AR. Electrophoretic deposition of chitosan-based composite coatings for biomedical applications: A review. Prog
Mater Sci. 2019;103:69-108. https://doi.org/10.1016/j.pmatsci. 2019.01.001.

39. Lei M, Qu X, Liu H, Liu Y, Wang S, Wu S, et al. Programmable Electrofabrication of Porous Janus Films with Tunable Janus Balance for Anisotropic Cell Guidance and Tissue Regeneration. Adv Funct Mater. 2019;29. https://doi.org/10.1002/adfm. 201900065.

40. Cheong M, Zhitomirsky I. Electrodeposition of alginic acid and composite films. Colloid Surf A. 2008;328:73-8. https://doi.org/ 10.1016/j.colsurfa.2008.06.019.

41. Li J, Kim E, Gray KM, Conrad C, Tsao C-Y, Wang SP, et al. Mediated electrochemistry to mimic biology's oxidative assembly of functional matrices. Adv Funct Mater. 2020. https://doi.org/10. 1002/adfm.202001776.

42. Seuss S, Lehmann M, Boccaccini AR. Alternating current electrophoretic deposition of antibacterial bioactive glass-chitosan composite coatings. Int J Mol Sci. 2014;15:12231-42. https://doi. org/10.3390/ijms150712231.

43. Stevanovic M, Djosic M, Jankovic A, Nesovic K, Kojic V, Stojanovic J. et al. Assessing the bioactivity of gentamicin-preloaded hydroxyapatite/chitosan composite coating on titanium substrate. Acs Omega. 2020;5:15433-45. https://doi.org/10.1021/acsomega. $0 \mathrm{c} 01583$.

44. Gray KM, Liba BD, Wang Y, Cheng Y, Rubloff GW, Bentley WE. et al. Electrodeposition of a biopolymeric hydrogel: potential for one-step protein electroaddressing. Biomacromolecules. 2012;13:1181-9. https://doi.org/10.1021/bm3001155.

45. Yan K, Xiong Y, Wu S, Bentley WE, Deng H, Du Y. et al. Electro-molecular assembly: electrical writing of information into an erasable polysaccharide medium. Acs Appl Mater Interfaces. 2016;8:19780-6. https://doi.org/10.1021/acsami.6b07036.

46. Dai G, Wan W, Zhao Y, Wang Z, Li W, Shi P, et al. Controllable $3 \mathrm{D}$ alginate hydrogel patterning via visible-light induced electrodeposition. Biofabrication. 2016;8. https://doi.org/10.1088/17585090/8/2/025004.

47. Wan W, Dai G, Zhang L, Shen Y. Paper-based electrodeposition chip for 3D alginate hydrogel formation. Micromachines. 2015;6:1546-59. https://doi.org/10.3390/mi6101438.

48. Bencherif SA, Sands RW, Bhatta D, Arany P, Verbeke CS, Edwards DA. et al. Injectable preformed scaffolds with shapememory properties. P Natl Acad Sci USA. 2012;109:19590-5. https://doi.org/10.1073/pnas.1211516109.

49. Leaper D, Muenter C, Meaume S, Scalise A, Blanes Mompo N, Jakobsen BP, et al. The Use of Biatain $\mathrm{Ag}$ in Hard-to-Heal Venous Leg Ulcers: Meta-Analysis of Randomised Controlled Trials. Plos One. 2013;8. https://doi.org/10.1371/journal.pone. 0067083

50. Wang B-L, Ren K-F, Wang HCJ-L, Ji J. Construction of degradable multilayer films for enhanced antibacterial properties. Acs Appl Mater Interfaces. 2013;5:4136-43. https://doi.org/10. 1021/am4000547.

51. Santo CE, Lam EW, Elowsky CG, Quaranta D, Domaille DW, Chang CJ. et al. Bacterial killing by dry metallic copper surfaces. Appl Environ Microbiol. 2011;77:794-802. https://doi.org/10. 1128/aem.01599-10.

52. Santo CE, Quaranta D, Grass G. Antimicrobial metallic copper surfaces kill Staphylococcus haemolyticus via membrane damage. Microbiologyopen. 2012;1:46-52. https://doi.org/10.1002/mbo3.2.

53. Hu X-J, Liu Z-X, Wang Y-D, Li X-L, Hu J, Lu J-H. Synchrotron FTIR spectroscopy reveals molecular changes in Escherichia coli upon $\mathrm{Cu} 2+$ exposure. Nucl Sci Techn. 2016;27. https://doi.org/ $10.1007 / \mathrm{s} 41365-016-0067-9$. 
54. Mao C, Xiang Y, Liu X, Zheng Y, Yeung KWK, Cui Z. et al. Local photothermal/photodynamic synergistic therapy by disrupting bacterial membrane to accelerate reactive oxygen species permeation and protein leakage. Acs Appl Mater Interfaces. 2019;11:17902-14. https://doi.org/10.1021/acsami.9b05787.

55. Li M, Li L, Su K, Liu X, Zhang T, Liang Y, et al. Highly effective and noninvasive near-infrared eradication of a Staphy- lococcus aureus biofilm on implants by a photoresponsive coating within 20min. Adv Sci. 2019;6. https://doi.org/10.1002/advs. 201900599.

56. Irwansyah I, Li Y-Q, Shi W, Qi D, Leow WR, Tang MBY. et al. Gram-positive antimicrobial activity of amino acid-based hydrogels. Adv Mater. 2015;27:648-54. https://doi.org/10.1002/adma. 201403339. 